\title{
Heroínas, gênero e Guerras:
} mulheres em periódicos militares (1942-1945)

Heroines, gender and Wars: women of military magazines (1942-1945)

Rosemeri Moreira 
Resumo: Este artigo é uma reflexão sobre a concepção de feminino(s) e de heroínas militares, presente na imprensa militar, no período de 1942-1945. Da véspera ao fim da participação do Brasil na $2^{\text {a }}$ Guerra Mundial, analiso as reportagens e notícias referentes a mulheres, de forma indireta ou direta, publicadas nas seguintes revistas militares: A Defesa Nacional e Nação Armada.

Palavras-chave: Imprensa militar; $2^{\text {a }}$ Guerra; Heroínas; Gênero.

Abstract: This article is a reflection about the conception of femininity(ies) and of military heroines, present in the military press from 1942 to 1945 . From the beginning to the end of Brazil's participation in World War II, I analyze the reports and news regarding women, directly or indirectly, published in the following military magazines: A Defesa Nacional e Nação Armada. Keywords: Military press; $2^{\circ}$ War; Women; Gender. 
As discussões da História do Corpo e dos Estudos de Gênero, desde fins do século XX, tem problematizado a naturalização, ainda recorrente, entre a ideia de militar e masculino/masculinidades (homens) e os usos sociais da violência. O processo de subjetivação da masculinidade viril está atravessado pela ideia e/ou experiência sobre a capacidade física e psicológica para infligir dor e sofrimento ao outro e a si próprio. A capacidade guerreira, culturalmente posta como inerente ao corpo dito masculino ${ }^{2}$, fez/faz da guerra (instituição) um lugar de construção e/ou reafirmação da masculinidade viril, a qual se funda, principalmente, na negação e oposição a ideia de um feminino. Este último, ao mesmo tempo em que é posto como frágil, carente de proteção, é fortaleza moral, sob o qual recai os motivos declarados da própria guerra: a família, as mulheres e as crianças ( CARREIRAS, 2009; MOREIRA, 2010; PERROT, 1998).

Diversas pesquisas já assinalaram que a presença de mulheres em conflitos, revoluções, guerras e batalhas foi constante na História (CAIRE, 2002; OLIVEIRA, 2006; SALAS, 1990). Entretanto, mais do que apontar as mulheres exceções, decantadas pelas instituições militares, a presença maciça de mulheres em combates (guerras, guerrilhas, revoluções) foi problematizada pelos Estudos de Gênero e pela História do Corpo, a partir da análise desse apagamento, confortavelmente instalado em enquadramentos epistemológicos. Como essas não poucas mulheres foram deixadas de lado pela historiografia (acadêmica e/ ou militar)? A partir de qual lógica teórica? Ou ainda, de que forma mulheres e o (s) feminino(s) foram/são apresentados em narrativas militares? Esta última questão é o objeto de reflexão deste texto ${ }^{3}$.

Nas lutas pela independência na América Latina, por exemplo, diversas mulheres participaram de batalhas, campanhas, guerrilhas e guerras, ocupando postos militares e funções militarizadas. Várias dessas mulheres foram transformadas em heroínas respeitáveis, sendo reenquadradas dentro de uma feminilidade específica, uma vez que, segundo seus biógrafos hispanoamericanos, guerrearam tomadas pela paixão e pelo sentimento, vendo-se obrigadas a lutar pela pátria, pelo companheiro ou pelos filhos (PRADO, 1999, p. 46). Na maioria das vezes, mesmo participando dos combates com função militarizada, não significava às mulheres ocupar o status de militar. Lutar em batalhas não significava "ser" um soldado, ou ter a honra de ser assim considerada. A presença de mulheres em atividades militares, e/ou militarizadas, foi negada em termos simbólicos, mais do que propriamente físicos. ${ }^{4}$

Pensando nas questões relativas a esses reenquadramentos de um feminino participante de batalhas e guerras, este artigo tem por foco discutir narrativas 
sobre mulheres na imprensa militar, especificamente nas Revistas "Nação Armada" e "Defesa Nacional”, entre 1942 e 1945. O objetivo é, a partir dessas análises, compreender qual feminino poderia ser benquisto, acolhido e narrado na perspectiva de militares e ou associados/as (reformados, aposentados, etc.) ao militarismo: o (s) feminino (s) possível.

Em primeiro lugar apresento, brevemente, as revistas militares sobre as quais foco a análise proposta, evidenciando suas características político-militares. Na sequência, analiso as reportagens, propagandas, notícias ou notas, que tem por foco assuntos em que mulheres são centrais.

\section{As revistas militares: "Nação Armada" e "A Defesa Nacional”}

A chamada imprensa militar se configura como um importante objeto de análise histórica ainda por se fazer, uma vez que são relativamente poucas as pesquisas que tratam da imprensa militar como objeto histórico. Segundo o historiador José Miguel Arias Neto, a maioria dos periódicos militares surgiram após 1850, a partir da estabilidade da politica conciliadora do Brasil Imperial, do período Saquarema, em que os militares foram estimulados a opinar sobre o futuro de suas instituições (ARIAS NETO, 2014, p. 61). Fernanda dos Santos Nascimento (2015, p. 27) também assinala que os militares, desde meados do Oitocentos, se dedicaram ao debate intelectual público sobre a instituição e os rumos da nação, geralmente voltados ao público militar.

A existência vigorosa da imprensa militar, no século XIX e no XX, se configura como um vasto campo de pesquisa tanto para a História da Imprensa, como para a História das instituições militares. Para Nascimento, analisar a imprensa militar é crucial para a compreensão dos discursos sobre "ser e pertencer à classe militar” (NASCIMENTO, 2014, p. 20). Os periódicos militares, assim como os demais periódicos, são espaços peculiares onde está presente uma determinada cultura política: o olhar que seus editores, jornalistas e articuladores tem sobre si, junto às representações sobre a vida social como um todo, estão estampadas de forma sutil ou explícita em suas páginas. Seja no editorial, nas reportagens, nas notas, nas propagandas, nos logotipos utilizados, na seleção dos temas, nas capas, etc.. As disputas econômicas, políticas e sociais estão presentes nos periódicos, traduzidas pelo olhar de seus articuladores. Disputas presentes na visibilidade dada, na ênfase direcionadora do periódico, ou pela própria negação, ausência e silenciamento. No caso deste texto, utilizo a imprensa militar como fonte para analisar a temática específica da ideia de feminino/ 
mulheres, (re)produzida por militares e/ou seus associados e articuladores.

É necessário situar, mesmo que de forma breve, as revistas em questão. Inicio pela revista Nação Armada, a qual, no período de 1942-1945, em comparação com as demais, foi a que mais publicou textos enfocando mulheres. A revista Nação Armada teve sua primeira edição publicada em novembro de 1939, dois meses após o início da $2^{a}$ Guerra Mundial ${ }^{5}$, e sua ultima edição é de março de 1947. Teve periodicidade mensal até janeiro de 1946 e após esse período passou a ser publicada irregularmente até seu fechamento. Denominada pelos organizadores e colaboradores como sendo civil-militar, esse periódico não era um veículo oficial do Exército, mas, segundo o Cel. Francisco Ruas Santos (1960), recebia subvenção estatal.

A Nação Armada contém pronunciamentos, visitas e excursões do presidente Getúlio Vargas; discursos do Ministro da Guerra, Eurico Gaspar Dutra e do Chefe do Estado-Maior do Exército, Góes Monteiro. Além dos assuntos estritamente militares (técnicos) a revista abordava assuntos relativos ao que era considerado papel do Exército na sociedade, se configurando como uma das principais fontes para o período do Estado Novo e o pensamento militar brasileiro (MONTEIRO, 2010, p. 65-66).

A revista Nação Armada contém propagandas e artigos, ensaios, notícias e reportagens escritas e/ou traduzidas por militares, políticos, jornalistas e intelectuais em geral ${ }^{6}$, os quais, segundo Vitor Monteiro, ajudavam a reforçar a ideologia do Estado Novo, pautada no autoritarismo e no nacionalismo como valor central para a construção da nação. Para esse autor, a revista:

\footnotetext{
[...] deu vazão a pensamentos e teorias, posicionamentos e atitudes, que não encontrariam o mesmo espaço e fluidez em outras publicações e instâncias da vida social: a germanofilia (mesmo após a declaração de guerra contra os alemães), o pensamento autoritário, racista, misógino, eugenista, antissemita e, por vezes, fascista (MONTEIRO, 2010, p. 43).
}

Esse viés representava a consolidação da união do projeto varguista e Exército Brasileiro, na defesa de um estado forte e centralizador, entrecruzado ao engrandecimento nacional e sob tutela militar. O estado de guerra, desde o título, o logotipo, e a linha editorial da Nação Armada, para além da preparação interna do Exército, propiciava discursos em que se pretendia militarizar o país, com a urgência de garantir seu êxito vindouro (MONTEIRO, 2010, p. 
64). Entretanto, para Monteiro, a revista não teve um pensamento único, uma postura conceitual, em relação ao regime estadonovista. Para esse pesquisador, Nação Armada representou muito mais a posição de disseminadora de ideias dos principais militares do período: o Ministro da Guerra Gen. Eurico Gaspar Dutra e o Chefe do Estado Maior do Exercito no Estado Novo Gen. Góes Monteiro?. Para Frank McCann (2007), a aliança entre o governo varguista e o Exército se concretizou, principalmente, através desses dois militares, unidos em torno de um projeto de nação, que almejava colocar o país sob o viés do autoritarismo e que considerava o Exército como disseminador do civismo, da nacionalidade e da preparação para a guerra que se avizinhava.

Como já assinalado, na Nação Armada eram publicados artigos com assuntos militares, assinados por fundadores ou colaboradores: memória militar, armamentos em geral, tecnologias de guerra, estratégia, psicologia do combatente, as especialidades das Forças Armadas, a importância dos militares, etc. Francisco Affonso de Carvalho, fundador e diretor de Nação Armada, à época major, é descrito por Monteiro como um homem de "encorpada vida política e literária” (MONTEIRO, 2010, p. 52). Affonso de Carvalho publicou em 1931, dentre outras inúmeras obras, um romance chamado “ $1^{\text {a }}$ Bateria, fogo!”, descrito na capa como o "Verdadeiro Livro da Revolução". Outro importante militar que fez parte da equipe da Nação Armada foi o General Francisco de Paula Cidade ${ }^{8}$, o qual havia ajudado a fundar a revista $A$ Defesa Nacional, em 1913, discutida a seguir.

A segunda revista em discussão, A Defesa Nacional ( $A D N)$, foi criada em 1913, por jovens oficiais (jovens turcos) ${ }^{9}$, e, segundo Fernanda Nascimento (2010, 2015), mesmo estando voltada ao corpo de oficiais da Marinha e do Exército, buscava se inserir no meio civil. Leonardo Trevisan relaciona a formação da $A D N$ à $1^{\text {a }}$ Guerra Mundial (1914-1918), demonstrando a importância das preocupações de militares para a vida de do país. Segundo ele, muitos de seus redatores e fundadores haviam participado de estágios em corpos de tropa alemães, entre o período de 1906 e 1910. Esses oficiais teriam expressado a sensação de desmerecimento no retorno ao Brasil e assumiram pra si a tarefa de modernizar a instituição (TREVISAN, 1993, p. 135).

Segundo Leila Capella, após a incursão na Europa, esses oficiais “[...] tinham em comum o desejo de incutir no Exército brasileiro uma cultura realmente profissional, ligada às necessidades da guerra moderna” (CAPELLA, 1985, p. 84), pautados pela ideia de atraso nacional e, principalmente, atraso do Exército em relação às congêneres europeias. A $A D N$ repercutiu amplamente entre o corpo 
de oficiais, principalmente, durante a década de 1930. Considerada por Capella como uma revista coesa nas décadas de 1910 a 1930, a $A D N$ se configurou como um importante lugar de disseminação de um "[...] discurso de militares relativos aos problemas nacionais, ao autoritarismo, ao comunismo e mesmo à indústria, foi a formação de uma base de pensamento que encontrou eco durante muitas décadas na instituição militar [...]” (NASCIMENTO, 2015, p. 78). De qualquer forma $A D N$ se configurava como uma sociedade civil, não ligada oficialmente ao Exército, mas composta pela intelectualidade de militares que ambicionavam o engrandecimento e defesa da Pátria ${ }^{10}$.

Para o período que aqui interessa, Nascimento (2015) considera que a $A D N$, para além do debate referente a modernização do Exército, foi um veículo crucial para a busca de coesão da instituição, no que ela chama de "depuração dos movimentos insidiosos" (NASCIMENTO, 2014, p. 14 ) no interior da instituição, próprios da década 1920. Coesão alcançada, na década de 1930, em torno de um projeto político-militar que se tornou ação, com a fusão entre interesses do governo Vargas e de militares, principalmente após a decretação do Estado Novo.

Importante assinalar que para Robert Hayes, a partir de meados da década de 1930, se dá justamente o contrário. Para Hayes, a $A D N$ deixou de ser o principal veículo de manifestação do pensamento dos militares em relação aos problemas nacionais, lugar que passou a ser desempenhado pela Revista Militar Brasileira (HAYES, 1991, p. 162). A intenção inicial da pesquisa era abranger a Revista Militar Brasileira na análise sobre narrativas sobre mulheres, sobre qual(is) feminino(s) estariam presentes em revistas militares. Entretanto, no período que nos interessa, a Revista Militar Brasileira se configura como um impresso dedicado estritamente a tecnologias e estratégias militares, e não contém nenhuma reportagem ou notícia referente à mulheres seja do presente ou do passado. Ao que tudo indica, o seu caráter estritamente militar, voltado a técnicas, tecnologias e estratégias de guerra, não permitiu brechas a discussões que minimamente pudessem envolver as mulheres, tais como as demais revistas que dialogavam com aspectos considerados civis.

Revista oficial do Exército, a Revista Militar Brasileira surgiu em 1882 com a denominação de Revista do Exército Brasileiro. De 1882 até os dias atuais recebeu diversas denominações, teve diferentes periodicidades e passou, ao longo desse longo período, pela responsabilidade de vários órgãos do Exército. ${ }^{1}$ Na década de 1930, a revista era editada pela Imprensa Militar, a qual estava subordinada ao Estado Maior do Exército. A partir do desmonte da República 
Velha, a equipe da revista estava formada por uma série de profissionais: revisores, paginadores, conferentes, impressores e encadernadores, somando mais de quarenta profissionais que compunham a imprensa oficial militar.

Durante o Estado Novo a Revista Militar Brasileira teve o caráter de veículo primaz do Exército. Esse foi o espaço oficial para a difusão do papel do Exército como construtor e condutor da salvaguarda da nação (MONTEIRO, 2010, p. 72) e na intervenção da instituição na política e na cultura do país, pensamento conhecido como doutrina Góes Monteiro. Nas páginas da Revista Militar Brasileira o Chefe do Estado-Maior do Exército, Gen. Góes Monteiro, publicou seu projeto de ação e o papel do Estado-Maior e do Exército do período Estadonovista (CARVALHO, 2005). A revista estava sob estrito controle de seus órgãos internos e não foi publicada entre 1939-1940, anos iniciais da revista Nação Armada, motivo desta última ter alcançado grande e rápida importância nos meios militares.

Uma diferença importante em relação a essas revistas, assinalada por Monteiro (2010) é a quantidade de propagandas veiculadas na Nação Armada, em detrimento das demais. ${ }^{13}$ Para o que interessa neste texto, entre 1942-1945, as reportagens, notícias, avisos ou propagandas, referentes a mulheres são ínfimas, demarcando a imprensa militar como um espaço de e para homens, para as masculinidades, mas que permitem entrever, qual o feminino possível, mesmo que diminuto, nesse espaço ${ }^{14}$.

Nas revistas aqui discutidas, a Nação Armada é a que contém mais textos que se referem diretamente a mulheres: um total de quatro artigos e uma notícia breve. Além disso, foi publicado um artigo de cinco páginas referentes ao sucesso da música/poema Lily Marleen (1915/1938), o qual contém o olhar do Gen. Paula Cidade sobre o sucesso da música nas trincheiras. Na $A D N$ existem somente duas referências diretas a mulheres, no período 1942 a 1945, e nenhuma referência, como já mencionado, na Revista Militar Brasileira.

\section{O feminino nas/das revistas militares}

Importante assinalar que a perspectiva de gênero busca desnaturalizar e historicizar as concepções de feminino/masculino, as quais, desde o século XVIII, na cultura ocidental, estão referidas em genitálias dimórficamente classificadas como sendo de homens ou mulheres ${ }^{15}$. Para os chamados Estudos de Gênero e para a História do Corpo a ideia de um feminino(s) como sendo automaticamente relativo a mulheres de carne e osso é base fundamental de 
questionamentos.

Um feminino (frágil, emocional, maternal), para Helena Carreiras, é a categoria que se configura como alteridade referencial à ideia de militar/ militares e militarismo, uma vez que as mulheres, nas palavras da autora, se encontram cristalizadas no interior da caserna pela sua ausência (CARREIRAS, 2009, p. 175).

Em ordem cronológica, o primeiro texto da Nação Armada que se refere diretamente a mulheres foi publicado em outubro de 1942, dois meses após a decretação da entrada do Brasil na $2^{\text {a }}$ Guerra, contra os países do eixo ${ }^{16}$. O texto trata da transcrição de um discurso que foi proferido pelo Cap. Dr. Carlos Sudá, em cerimônia de juramento das chamadas "Samaritanas", no dia 23 do mesmo mês, no teatro municipal do Rio de Janeiro. As samaritanas, referência à parábola cristã sobre a compaixão, eram mulheres que haviam realizado curso de enfermagem de apenas um ano, frente à urgência da guerra advinda.

Acima da manchete: "Saudação à Caxias e Ana Nery", consta um desenho, assinado por Alberto Lima (Figura 1). Olhando na mesma direção que Caxias, Ana Nery (grafia da fonte) está posta como ligeiramente maior do que o desenho do grande herói.

Figura 1 - Saudação à Caxias e Ana Nery

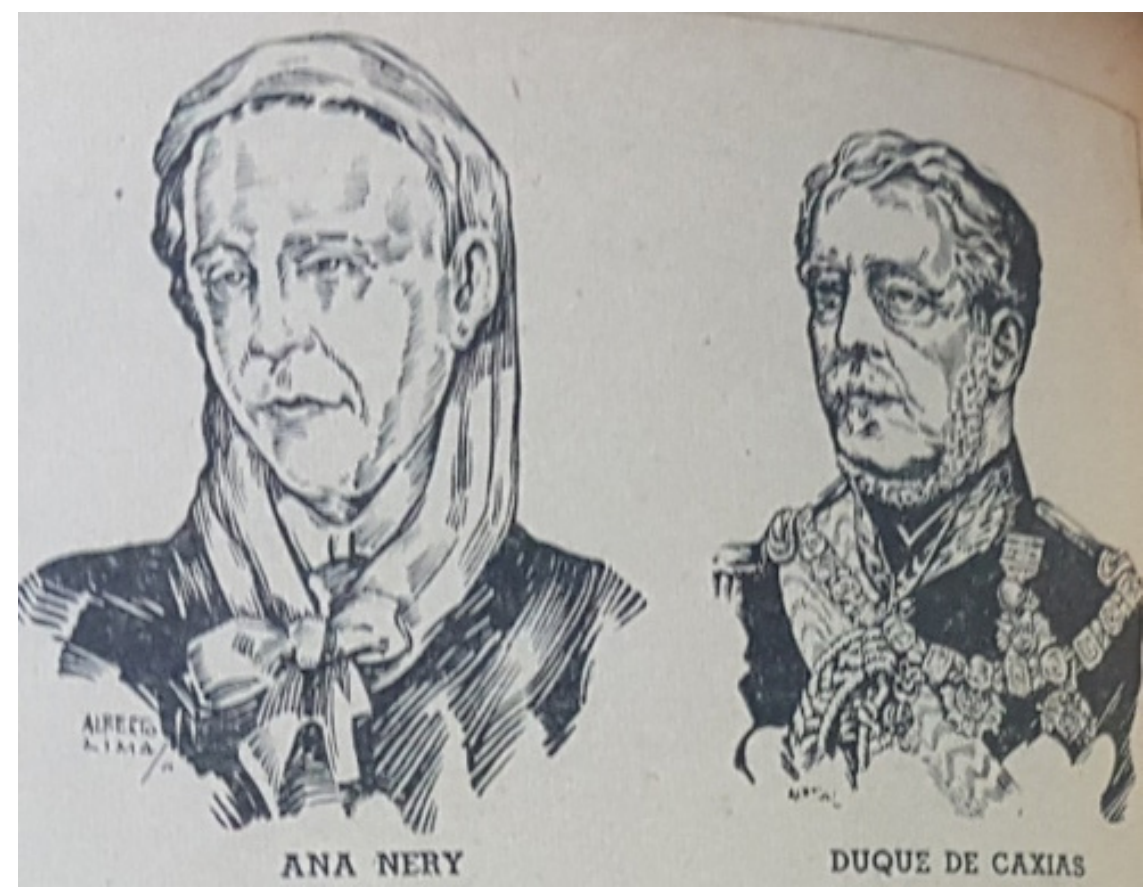

Fonte: ANDRADE, Cap. Dr. Carlos Sudá. Nação Armada, n. 35, out. 1942, p. 34. Acervo: Biblioteca do Exército - BIBLIEx. 
A heroína Ana Nery se configura como a imagem de devoção e sacrifício de mulheres em períodos de Guerras ${ }^{17}$. A imagem da enfermeira - aquela que cuida, que salva os homens feridos, destroçados, machucados, física e moralmente, ainda se apresenta como uma das principais representações coletivas sobre a presença de mulheres na $1^{\mathrm{a}}$ e na $2^{\mathrm{a}}$ Guerra Mundial, a despeito das pesquisas que, reiteradamente, apontam a diversidade de ações empreendidas (CAIRE, 2002; QUETEL, 2009).

Sobre a ilustração, importante assinalar que o principal responsável pela parte gráfica e artística da revista Nação Armada foi Alberto Lima (1898-1971), o qual era formado no Liceu de Artes e Ofício do Rio de Janeiro. Segundo Monteiro, ele foi um importante desenhista, ilustrador e heraldista, reconhecido em todo o Brasil pela criação de vários brasões de municípios; foi o criador do símbolo da Força Aérea Brasileira (o gládio alado); desenhou diversos símbolos e uniformes militares, principalmente quando dirigiu o Gabinete Foto-cartográfico do Exército, na década de 1940 (MONTEIRO, 2010, p. 45). O Cel. Francisco Ruas Santos (1960, p. 411) considera que a Nação Armada foi a publicação militar mais bem feita em termos gráficos e artísticos. De qualquer forma as imagens da revista se configuram num didatismo gráfico, a partir de desenhos que acompanham alguns textos.

O enunciado do capitão médico, na ocasião do solene juramento das samaritanas, tratava de fazer uma comparação entre os dois vultos, os quais, de maneira diferente - homem e mulher, masculino e feminino-, estão postos de forma equivalente e complementar: "Duas vidas gloriosas, duas vidas eternas, duas vidas sagradas que a mesma bandeira abençoa e que a mesma pátria dignifica no culto de seu amor e na unção do seu respeito!” (ANDRADE, 1942, p. 34). A mesma bandeira, porém, duas formas complementares de protegê-la:

Duas vidas feitas de luz, duas vidas heróicas, duas vidas de sacrifícios ingentes, de bravura exemplar, de trabalho construtor, de sublimes renúncias, de perene fervor à terra do seu berço e da candente vigília ao amor de seus irmãos, à lagrima dos aflitos, às dores dos vencidos e à glória do Brasil! A espada e a cruz! A espada do guerreiro audaz, do gênio das batalhas, do soldado perfeito, a espada de Caxias! A cruz da piedade anônima, da samaritana silenciosa, da enfermeira voluntária dos campos de peleja, A Cruz Vermelha que mitiga a sede, que sacia a fome, que pensa as chagas jorrantes, que alivia as dores cruéis, a cruz-coração de Ana 
Nery! O soldado e a enfermeira, os dois polos magnéticos em que se encarnam a bravura do homem e a bravura da mulher; as duas estrelas guias, os dois clarões de glória: um, retumbante como um hino, outro, murmurando como uma prece; um, ardente como o sol, outro níveo como a lua; Caxias e Ana Nery que esculpiram na História Pátria, os exemplos singulares da Honra e do Dever! Tao grandes os dois, fulgem, como pendões da Raça, abençoados pelas bandeiras que juntos os viu um dia, no arremesso dos combates, entre clarinetes e feridas, entre estridores e gemidos, palmilhando a estrada estrelada da Imortalidade! Glória a ti, Duque de Caxias! Glória a ti, Ana Nery! Vós ambos que sagrastes, igualmente, pela vossa vida peregrina, o supremo privilégio de se nascer no Brasil! (ANDRADE, 1942, p. 34, sem grifo no original).

As semelhanças entre ambos - o sacrifício; bravura; renúncia; amor/ fervor pela pátria; vigília pelos patrícios, - são avultadas. Entretanto, a complementaridade das diferenças, postas como inerentes, é que marcam a necessidade e o êxito da aproximação - "pólo magnético" - entre eles: o soldado e a enfermeira. Em diferentes bravuras: ora retumbante, ora como sussurro e prece; um exigindo, outro pedindo; a brilhosa ostentação do sol e a pálida discrição da lua. A exigência da espada pela morte e o sacrifício da cruz em busca da preservação de vidas. Essa alegoria, pronunciada às samaritanas pelo médico capitão, explicita o caráter benemerente, caritativo, sacrificial e, principalmente, os cuidados próprios a mulheres, em nome de um feminino mitificado como redentor em um lugar de sofrimento.

Importante observar que logo após a publicação do decreto referente a criação da defesa passiva em território nacional, assinado pelo presidente Getúlio Vargas, em fevereiro de 1942, grupos de mulheres se prontificaram em auxiliar os militares em defesa da Pátria. No mesmo mês, o Diário de Notícias publicou a visita das diretoras da Fundação Osório (Cassilda Martins), da Secção Feminina da Cruz Vermelha Brasileira, (Elizabeth Gomes) e a presidenta da Secção Feminina da Cruz Vermelha de São Paulo, à Secretaria Geral do Ministério da Guerra, ao Gen. Benício da Silva, “[...] a fim de pedirem instruções práticas relativas a defesa passiva. Essas senhoras tomaram essa louvável iniciativa com o propósito de difundir no seio da população as regras de primeira urgência contra possíveis ataques." (Diário de Notícias, 1942, p. 3). A preocupação com a defesa passiva, antes mesmo da entrada oficial do Brasil na guerra, está presente nos jornais brasileiros, e o papel a ser desempenhado 
pelas mulheres foi ficando cada vez mais evidente: tanto com a criação da Legião Brasileira de Assistência (LBA), quanto nos primeiros cursos sobre defesa passiva e enfermagem de urgência, oferecidas pela Escola Técnica de Serviço Social. Além das samaritanas, as voluntárias da defesa passiva antiaérea, paulatinamente, foram organizadas como OFAGs: Organização Feminina Auxiliar de Guerra.

A Força Expedicionária Brasileira (FEB), criada em fevereiro de 1943, seguiu à Europa somente em $1944^{18}$. O ano de 1942 é marcado pela preocupação com a chamada defesa passiva anti-aérea, como posto acima, a qual englobava a necessidade de participação maciça de mulheres em atividades diversas.

A segunda reportagem sobre mulheres foi publicada na Nação Armada em novembro de 1942. O título do longo artigo (sete páginas): "O heroísmo feminino. Homenagem a Legião Brasileira de Assistência”, nos aponta a finalidade e a preocupação com o reconhecimento de ações de mulheres ao longo de marcos oficiais de um passado glorioso do Exército Brasileiro, em um momento crucial de convocação às mulheres ao esforço de guerra. As lideranças militares, bem como políticos e organizações femininas, tais como a LBA, também se voltaram a enunciados que responsabilizavam mulheres pela defesa da Pátria (BARBOSA, 2017).

A LBA foi fundada concomitantemente a entrada do Brasil na $2^{\text {a }}$ guerra, em 28 de agosto de 1942 , pela $1^{\text {a }}$ dama Darcy Vargas, com a finalidade declarada de "[...] amparar os soldados brasileiros e seus familiares" por parte dos "brasileiros de boa vontade" (BARBOSA, 2017, p. 21). A LBA, fundada pela parceria Estado e empresariado brasileiro, tinha como base de sustentação o chamado voluntariado feminino, abrangendo todo o território nacional e inaugurando o que foi chamado de $1^{\circ}$ damismo (SIMILI, 2008). Para Ana Paula Vosne Martins, a organização da LBA, voltada a assistência social, é um indicativo de como o Estado Novo criou as condições para o exercício do que a autora chama de "cidadania feminina”. Era a difusão da ideia e de práticas em que as mulheres seriam de suma importância na ocupação do espaço público, utilizando a maternagem enquanto prática política, uma vez que voltada a toda a sociedade ${ }^{19}$, e que já estava acontecendo nos regimes autoritários europeus: estado novo salazarista, na Itália fascista e na Espanha franquista (MARTINS, 2011, p. 16). A crença nas capacidades de salvaguarda moral e física de toda a família, inerentes a um feminino doméstico, privado, mas expandido ao espaço púbico, fazia parte do debate político brasileiro, pelo menos desde fins do século XIX, sobretudo, com a eclosão do debate sufragista (SOIHET, 2006). 
A reportagem, assinada pelo Cap. Micaldas Correia, inicia observando que as mulheres já participavam ativamente de amplos espaços da sociedade: “[...] Nos lares e nas escolas, nos hospitais e nos laboratórios, nas fábricas e nos campos, em todas as atividades pacíficas, avulta a personalidade da mulher brasileira.” (CORREIA, 1942, p. 33). Entretanto, completa: a situação de guerra exige um novo esforço. Nas enfermarias, curando os feridos; nas fábricas; nos transportes e até nas milícias. Sobretudo, destaca a função das mulheres na preparação moral dos filhos à guerra, bem como o esposo ou irmão. Na sequência, o capitão passa a narrar, como, várias mulheres, com essa função - esteio moral -, haviam sido fundamentais a vitórias militares do passado.

Capitão Correia aborda no texto um total de treze heroínas, descritas de forma cronológica: quatro relativas à Batalha dos Guararapes (abril de 1648 e fevereiro de 1649); duas sem precisão de período/evento; duas relacionadas a luta pela independência (1822); uma referente a Guerra de Farrapos (18351845); quatro participantes da Guerra do Paraguai (1864-1870).

Em relação às heroínas da Batalha de Guararapes, primeiro ou segundo confronto, o artigo enumera e descreve as seguintes mulheres: Clara Camarão, esposa de herói Potí, como a “[...] mulher índia, lutou sempre ao lado de seu marido" (CORREIA, 1942, p. 33); Maria de Souza, mãe que,

Depois de ter perdido três filhos e o genro, não se abateu. Ao contrário, cresceu-lhe o sentimento de revolta. Restavam-lhe dois filhos, um de 13 e outro de 14 anos. Mandou-os também para a luta, dirigindo-lhes as seguintes palavras - 'Hoje foi vosso irmão Estevão morto pelos holandeses; a vós agora toca cumprir o dever de homens honrados, numa guerra em que se serve a Deus, ao Rei e à Pátria. Cingí as espadas, e, quando vos lembrar o triste dia, em que as pondes à cintura, inspire-vos ele não mágoa, mas no desejo da vingança que, quer vingueis vossos irmãos, quer sucumbais como eles, não degenereis deles, nem de mim.” (CORREIA, 1942, p. 33)

A devoção das mulheres mães à defesa da pátria é posta acima da vida dos filhos. Essa é uma narrativa que se repete em relação às demais personagens mães. A cobrança da defesa e manutenção da honra masculina é posta como uma exigência da mãe, do feminino, aos homens. Em narrativa parecida, Correia relata que Dona Ana Pais, descrita como senhora de engenho de Pernambuco, 
no momento em que era mantida refém, junto a outras mulheres, como escudo, por um grupo de sodados holandeses, teria proclamado: “'Atirem! Não se importem conosco! Atirem!' Resolveram então os brasileiros assaltar o engenho à arma branca, correspondendo à abnegação das mulheres com redobrada bravura" (CORREIA, 1942, p. 33). A coragem das mulheres, o destemor frente à morte eminente, serve de alavanca à exigência da coragem dos homens, os quais precisam corresponder à dita abnegação delas com a bravura e ferocidade necessária ao embate. A narrativa de Correia sobre as chamadas "Mulheres de Tejucupapo" segue na mesma direção:

Poucos homens válidos haviam; o mais, eram velhos, mulheres e crianças. [...] Há um esmorecimento. Mas, uma das mulheres, com um crucifixo numa das mãos e uma espada na outra, transfigurada, heroica, incentiva o combate. Então, as mulheres, tomando as armas dos homens caídos, contra-atacam, investem, desorientam e assombram o inimigo, que recua desordenado. (CORREIA, 1942, p. 34).

As Mulheres de Tejucopapo ${ }^{20}$, a partir da iniciativa de uma delas, conseguiram desorientar os homens/inimigos quando assumiram o papel de combatentes, retirando e usando as armas dos homens mortos ou feridos, não mais “válidos”. Essa narrativa, publicada em um momento que urgia o voluntariado de mulheres para o esforço de guerra, de forma muito semelhante, são atualmente celebradas por grupos políticos de viés antagônico ${ }^{21}$.

Como já dito, duas heroínas, descritas na sequencia das demais, não tem uma temporalidade específica. Segundo a rememoração enaltecedora do Capitão Correia, Dona Rosa Maria de Siqueira - "paulista, ilustre, em companhia do marido" (CORREIA, 1942, p. 34), foi a protagonista em uma vitória contra ataques consecutivos de piratas - cinco ataques -, por não permitir o esmorecimento dos homens: "Alguns homens da tripulação pretenderam entregar o barco, mas Dona Rosa exaltou-os, dizendo-lhes que era preferível a morte à capitulação. Depois, trajando-se de homem, integrou-se a peleja" (CORREIA, 1942, p. 35). A bravura e o enfrentamento de mulheres a condições adversas ao seu sexogênero, presentes na cultura, exigem dos homens a assunção ou retomada de seus lugares, de sua masculinidade viril, simbolicamente de antemão demarcada.

Outra heroína, também temporalmente não definida, é Maria Bárbara, 
descrita como esposa de um soldado humilde, mas que "sacrificou a vida pela honra conjugal, reagindo a perseguição de um devasso que tentara seduzila. Assaltada pelo miserável, em lugar ermo, resistiu valorosamente, em luta desigual e titânica, até cair assassinada" (CORREIA, 1942, p. 35). Na sequência, o capitão transcreve um soneto que teria sido feito a ela por Tenreiro Aranha, homenageando a pureza de uma mulher que defendeu a honra conjugal, leia-se, do marido, com a própria morte. As heroínas que são descritas como jovens e solteiras, sempre com "extrema formosura", seguem o mesmo padrão de defesa moral que culmina na própria morte, frente a ataques sexuais ocorridos em meio a confrontos e batalhas.

Todo o texto do Capitão Correia está entremeado com pequenas ilustrações, em laranja, de algumas dessas mulheres. Cronologicamente os inimigos vão mudando. Dos holandeses invasores, para o português opressor, duas heroínas das lutas pela independência (1822) - Soror Angélica e Maria Quitéria-, exemplificam também aquelas que não titubearam e tomaram para si a defesa do convento, da terra, da Pátria. No famoso ataque ao convento da Lapa pelos portugueses, segundo a narrativa do Cap. Correia, a soror teria bramido: "Para trás bandidos! Respeitai a casa de Deus! Antes de conseguirdes vossos infernais desígnios, passareis por sobre o meu cadáver' e tombou golpeada à espada” (CORREIA, 1942, p. 35).

Maria Quitéria, por sua vez, é descrita pelo capitão de forma breve. Talvez por se tratar de personagem mais conhecida que as demais, mesmo em $1942^{22}$. Ela teria fugido de casa e se alistado no Batalhão de Voluntários de Dom Pedro I, com indumentária masculina. Em 1823, uma vez descoberta sua condição de mulher, foi recebida por Dom Pedro, o qual lhe concedeu o soldo de alferes de linha e a condecoração de Cavaleiro da Ordem Imperial do Cruzeiro ${ }^{23}$. Sua imagem se encontra consolidada na história oficial do Exército, carecendo de pesquisa acadêmica específica.

Na narrativa de Correia, outra personagem também consolidada na cultura histórica sobre a Guerra de Farrapos, Anita Garibaldi, exemplifica a intervenção de mulheres em combates e que coloca a masculinidade/virilidade dos homens em cheque:

Certa vez, num combate entre navios, descendo de um posto abrigado, atravessou uma zona perigosa. Quiseram detê-la, 'Vou sim, para buscar os covardes que se esconderam lá em baixo!' Dali a pouco voltava, conduzindo um grupo de marinheiros, que se 
atiraram à luta, envergonhados (CORREIA, 1942, p. 36).

A vergonha dos homens, perante o chamamento à ordem, descrita por Correia, tem esse efeito justamente por se tratar de uma exigência feita por uma mulher. Mulher/feminino vista como espécie e simbolicamente posta como avessa a coragem, e que, fora de seu lugar, coloca em flagrante a situação de fraqueza de homens. O deslocamento da condição de masculinidade se dá, não somente pela hesitação, medo e indecisão perante o combate, mas, principalmente pela presença aguerrida de mulheres nele.

Na Itália, a Anita descrita pelo capitão, na condição de “[...] Grávida de cinco meses, faminta e ardendo em febre, não resistiu e morreu heroicamente" (CORREIA, 1942, p. 36). Os filhos já nascidos, ou os filhos ainda por nascer, não impedem a bravura dessas mulheres. Muito pelo contrário. É justamente esses lugares de um feminino como mãe sacrificial e esposa devotada que são aclamados no chamamento de outras mulheres ao esforço de uma guerra premente, e, principalmente, na exigência de tomada de brios aos homens.

Por fim, Capitão Correia delineia a participação heróica de quatro mulheres na Guerra do Paraguai. No chamado Ataque ao Forte de Coimbra (1864), Ludovina Portocarrero é descrita como “[...] digna de seu marido. Incentivava os homens ao combate e chefiou um grupo de 70 mulheres que ali permaneceram, contribuindo para a resistência, preparando e confeccionando munição para o que usaram até as próprias roupas” (CORREIA, 1942, p. 37). A Francisca Conceição, pernambucana, que com 13 anos, teria se casado com um cabo e seguido, disfarçada de homem, junto com ele para o sul do país para lutar: “[...] ela assiste à morte do companheiro. Jura vingá-lo” (CORREIA, 1942, p. 37). Ferida em Curupaiti (1866), no hospital descobrem que é uma mulher. Correia termina esse relato sem nos revelar o desfecho. A história dela ali se encerra. A ênfase dele é em demarcar a devoção de uma esposa que entrou em combate, primeiro, para acompanhar o marido e, depois, para vingá-lo. Em relação a Ludovina, “digna de seu marido”, ao ocupar lugar de comando e combate, assinala o despojamento de mulheres, até das próprias roupas, para não se deixar sucumbir ao inimigo. Essas mulheres são descritas tal qual aquelas que lutaram nos processos de independência em toda América Latina, discutidas por Maria Ligia Prado (1999). Além disso, é importante assinalar que a produção histórica ainda carece de pesquisas em relação ao que parece não ser tão raro nas guerras modernas: mulheres disfarçadas e/ou vestidas como homens, acompanhando os maridos/filhos, ou não, e fazendo parte dessas tropas. 
Mais uma importante personagem narrada pelo Cap. Correia, nada mais é do que a senhora Rosa da Fonseca, mãe do Marechal Deodoro. Somente no final da narrativa sobre seu heroísmo Correia fornece essa informação. O fio condutor do texto coloca sua bravura e importância histórica como sendo anterior e derivativa ao seu ilustre filho:

[...] nascida em alagoas, mãe de sete filhos homens, os quais lutaram todos na guerra do Paraguai. Cogitação de tratado de paz com o inimigo, declarou: "Prefiro não ver mais meus filhos! Que fiquem antes todos sepultados no Paraguai, com a morte gloriosa no campo de batalha, do que enlameados por uma paz vergonhosa para a nossa Pátria! (CORREIA, 1942, p. 38).

Com o recebimento da notícia de que um dos filhos tinha sido morto e outros dois feridos (um deles Deodoro), segundo o capitão, Dona Rosa chorou mais uma vez o sacrifício da prole, mas "[...] comemorou a vitória mandando iluminar a fachada da casa e enfeitando-a de flores e bandeiras. Nesse dia, em que se misturavam a dor e a alegria, disse ela: 'A vitória que a Pátria alcançou, e que todos foram defender, vale muito mais que a vida de meus filhos.'” (CORREIA, 1942, p. 38). A Pátria, acima de todas as coisas, mesmo para as mães, embala as narrativas militares sobre suas heroínas. A ideia de Pátria se mescla a ideia de uma família coletiva, nacionalmente preparada para os sacrifícios necessários a sua manutenção e/ou vitória, em que o decantado amor materno não poderia interferir. Longe disso. São as mães, são as esposas, são as mulheres que conduzem, induzem, dão ânimo a luta e ao sacrifício dos homens.

Dona Rosa da Fonseca foi elevada a categoria de "Patrono da Família Militar", em 2016. A família militar, categoria recentemente utilizada em pesquisas sobre militares (Ver: CASTRO, 2018), é enfatizada pelo Exército: “[...] na figura de Rosa da Fonseca, reconhecendo a importância do espírito de sacrifício e de luta, o qual possibilita aos integrantes da Força Terrestre alcançarem o sucesso pessoal e profissional, com o sentimento de dever cumprido, seja qual for a missão" ${ }^{24}$. Assim como as diversas heroínas, na família militar a função das mulheres é impulsionar o brio e a valentia dos homens, sem lugar para o lamento das inevitáveis perdas. Importante assinalar que a categoria nativa "família militar" se refere a fazeres, desejos, atribuições, e qualificações, atribuídas e naturalizadas a seus componentes de forma diferenciada, posto que generificada. 
Relatando a história de mais uma heroína da Guerra do Paraguai, capitão Correia escreve sobre a baiana Ana Justina Ferreira - Ana Neri - que casou com Izidoro Antonio Neri, oficial da Marinha. Teve três filhos homens: dois médicos e um militar. Cedo enviuvou. Com a partida dos filhos para a guerra, a mesma teria escrito ao presidente da província da Baía, em 8 de agosto de 1865:

[...] como brasileiro [sic], não podendo ser indiferente aos sofrimentos dos meus compatriotas, e, como mãe, no podendo resistir à separação dos objetos que me são caros, e por uma tão longa distancia, desejava acompanha-los por toda a parte, mesmo no teatro da guerra, se isso me fosse permitido; mas opondo-se a esse meu desejo e minha posição e o meu sexo, não impedem, todavia, esses dois motivos, que eu ofereça os meus serviços em qualquer dos hospitais do Rio Grande do Sul, onde se façam precisos, com o que satisfarei ao mesmo tempo meus impulsos de mãe e os desejos de humanidade para com aqueles que oram sacrificam suas vidas pela honra e brio nacionais e integridade do Império (CORREIA, 1942, p. 38)

Mãe e patriota, categorias em fusão no pensamento militar, Ana Neri, presente na revista em publicação anterior contrabalançando a cruz da abnegação, tenacidade e cuidado com a espada vitoriosa de Caxias, na carta apresentada pelo capitão, lança justamente sua "posição e sexo" como argumento à utilização de seus serviços na proximidade da guerra, ampliando sobremaneira a sua posição de mãe, cuidadora e benfazeja, às demais pessoas. Uma mãe de toda a nação. Segundo Cap. Correia, ela teria sido consagrada pelo Exército como a "Mãe dos Brasileiros". Entretanto, essa alcunha lhe foi dada a partir do poema escrito por Rozendo Muniz Barreto ([1876]), estudante de medicina, o qual teria sido testemunha da atuação de Ana Neri. Cap. Correia destaca que aos 50 anos, durante cinco anos, ela acompanhou as campanhas " [...] enfrentando pestes, cuidando de feridos, consolando enfermos, organizando enfermarias com recursos próprios. Tratava aliados e inimigos com o mesmo carinho, e os doentes chamavam-na de 'mãe”' (CORREIA, 1942, p. 39).

Importante assinalar que, em 1938, Getúlio Vargas havia instituído o Dia do Enfermeiro, a ser celebrado em 12 de maio. O decreto determinava que nessa data deveriam ser prestadas homenagens especiais a memória de Ana Neri em todos os hospitais e escolas de enfermagem (BRASIL, 1938). A flexão de gênero nos diplomas profissionais de homens e mulheres só passou a ser utilizada 
a partir de decreto presidencial de 2012, após problematização, tanto dos movimentos sociais quando das teorias feministas sobre a linguagem e relações de poder, e as críticas pós-estruturalistas ao chamado masculino universal ${ }^{25}$.

Capitão Correia finda seu texto enaltecendo um feminino relacionado a um ideal militar de mãe e esposa: protagonistas da elevação moral dos homens, seja pelo exemplo de coragem que chega a os envergonhar, seja pela abnegação ou até exigência do sacrifício da vida dos filhos, do marido e de si mesma; ou ainda pela manutenção da elevada moral e honra do marido:

A colaboração feminina na família e na sociedade, marca de bondade, inteligência, dedicação e espirito de sacrifício, tem provado à larga o valor e a grandeza moral da mulher brasileira. Mãe e educadora, mulher da ciência ou artista, enfermeira ou operária, a mulher contemporânea, livre de preconceitos, emancipada e conciente [sic], é fator decisivo nos destinos do Brasil, na preservação dos ideais de justiça e de humanidade (CORREIA, 1942, p. 39).

O próximo texto da Nação Armada sobre mulheres foi publicado em novembro de 1943 e se trata do artigo de Edith McNamara, com o título "As mulheres na guerra”. Em quatro páginas, McNamara (1943), utilizando pesquisas de universidades estadunidenses, argumenta sobre a necessidade e sucesso do trabalho de mulheres em fábricas nos EUA, principalmente, em fábricas de armamentos. Condizendo ao feminismo estadunidense do período, McNamara argumenta que esse sucesso poderia ser expandido com a adoção de cargas horárias menores, que possibilitariam um melhor aproveitamento do trabalho das mulheres mães.

Em 1943, o voluntariado de mulheres, seja atuando pela LBA ou em outras agremiações ditas femininas, já era uma realidade e tomava conta do esforço de guerra brasileiro. Importante assinalar que a tradução (sem nome) e publicação desse texto na Nação Armada, indica a consideração de militares brasileiros de que as mulheres estariam aptas a inúmeras tarefas, fora do âmbito familiar e privado.

Em 1945, dois meses antes do retorno da FEB ao Brasil, a Nação Armada retoma uma vez mais a imagem da enfermeira, com uma homenagem de uma página. O título - "O Heroísmo das legionárias de Anna Nery!"-, seguido de desenho e texto, com muitos pontos de exclamação, exaltava: 
Mulheres do Brasil estão no front! Trocaram as doçuras do lar e as seduções a vida social tranquila pelas canseiras e os perigos de ásperas jornadas no meio das ruínas, em cidades, montes e vales que a guerra devastou. [...] legionárias da bondade, sacrificam-se numa tarefa heroica, sob a tutelar inspiração de Anna Nery. [...] temos o dever de evoca-las para o culto do nosso carinho e da nossa saudade. [...] remeta a sua contribuição à Legião Brasileira de Assistência e à Liga de Defesa Nacional, sendo um entusiasta das abnegadas patrícias que renunciaram aos gozos materiais para que a humanidade pudesse recuperar, com a liberdade, o direito de viver em paz num mundo em todos se amem como irmãos (O HEROÍSMO..., 1945, p. 135).

Para além das enfermeiras que logo retornariam do front, no texto, a deferência é para todas as “abnegadas patrícias” que trabalharam de forma sacrificial pela pátria. A dicotomia espaço público/privado, explícita, reafirma esses lugares como forjados pelas oposições paz/guerra, perigo/proteção, casa/ rua, descanso/esforço; prazer material e vicissitudes. Além disso, esse esforço de mulheres está posto como fundamental a recuperação de uma mítica sociedade. No desenho que acompanha o texto há uma mulher/enfermeira em primeiro plano, olhando entre as ruínas (segundo plano), como se estivesse descortinando a esperança. Atrás dela, um homem convalescendo enfaixado. Um capacete estabelece a ligação entre os dois, além de uma estrela, ao alto, que os ilumina.

Aúltima notícia referente a mulheres que consta na Nação Armada, no período aqui discutido, é uma breve nota, publicada em outubro de 1945, noticiando o recebimento da Medalha de Guerra, pela $1^{\mathrm{a}}$ dama Darcy Vargas. A nota relata que a medalha, recebida diretamente das mãos do Gen. Góes Monteiro, foi encaminhada ao Museu Histórico, após pedido de Darcy, como homenagem a todos os civis “[...] que na retaguarda, contribuíram com qualquer parcela para a vitória final dos soldados do Brasil.” (A SRA..., 1945, p. 119). Com esse gesto político, Darcy Vargas reparte com os demais civis o sucesso da empreitada de sua ação pessoal à frente da LBA.

Na edição de dezembro de 1944, logo após o editorial, o qual discorria sobre o significado de um natal em meio à guerra, a Nação Armada publicou um artigo do Gen. Francisco de Paula Cidade, sobre a famosa canção Lily Marleen ${ }^{26}$. Cidade apresenta a história da música ao leitor e na sequência insere no texto a letra da canção em alemão, em italiano, em inglês, e na versão do português 
brasileiro. Por fim, a partitura. Cidade, como se falasse ao pé de ouvido do leitor, relata:

\begin{abstract}
Vou contar a história afortunada de uma canção de marcha que, como se fosse mulher bonita, viu-se sequestrada pelos soldados de todos os exércitos em luta, ontem na África e hoje na Europa. [...] Lily Marleen é uma entidade universal, de mulher que gosta de farda e que deixa uma suave recordação, por onde quer que passe [...]. É dactilógrafa, arrumadeira, caixeira de bazar, cozinheira ou ainda não tem profissão. É a mulher moça que tem alguma coisa que bate, como caixa surda, quando ouve corneta e sabe dizer cousas encantadoras à luz dos candieiros [sic] ou mesmo no escuro das ruas mais ou menos desertas. Não tem medo de abraços demorados, mas usa, como norma de conduta, fingir que o teme... Põe a mão no peito do amiguinho ocasional, para afastálo, entre suaves conselhos de um "Chega pra lá” insincero, mas queixoso como a arulho de uma pombinha a que se tenha tomado pelas asas [...] (CIDADE, 1944, p. 5).
\end{abstract}

Assim como a moça da canção - Lily Marleen - , sob o olhar do Gen. Cidade a própria música é uma mulher. Linda, desejada e tomada para si, por todos os beligerantes. A ênfase do general, relacionando o sucesso da música à universalidade dessa mulher "que gosta de farda”, a pombinha sempre próxima aos quartéis, utilizando de um ar de galhofa na escrita, contrastando com a nostalgia da melodia, mascara o que talvez seja a universalidade da condição do soldado, do combatente: a solidão, a melancolia, a angústia, a necessidade de sentir a presença da casa/família/afeto. Tudo aquilo que possa significar um breve alento, um afago, uma carícia em meio a dor, ao sofrimento, ao pavor, a iminência das batalhas e, quiçá, da morte. A música, mesmo que insinuado por Cidade, mais do que referência a sexo, ou a prostitutas, não nomeadas na canção, traz a nostalgia de um afeto possível. Mais do que sobre as mulheres, Lily Marleen e seu sucesso parecem dizer muito mais sobre os homens/ masculinidades e o sofrimento dos combatentes, sobre permitir-se recordar um outro lugar. A música é estar em outro lugar ${ }^{27}$.

Avançando na discussão, na revista $A D N$ existem somente duas referências diretas a mulheres, no período 1942 a 1945. A primeira é o texto do Gen. Silveira de Melo, sobre "Santa Bárbara: padroeira da artilharia”, publicada na edição de maio de $1944 .^{28}$ Em meio a artigos sobre a velhice; sobre a obra meritória de Marechal Hermes da Fonseca; sobre forças blindadas; instruções como orientar 
a juventude; sobre as vantagens e desvantagens da utilização de equídeos de carros, etc.; e editorial agradecendo e parabenizando o presidente Vargas pelo aniversário, Gen. Silveira de Melo narra a história da santa, "virgem e mártir”, que teria existido na região de Bitínia, Oriente Médio, incorporada ao império romano e evangelizada por São Pedro. Os detalhes da narrativa, mergulhados em um olhar generificado, mostram um profundo conhecedor da história da Igreja Católica.

Descrita como “[...] uma jovem de rara beleza e formosura” (MELO, 1944a, p. 898), filha única de um rico negociante que a trancou em uma torre para esse fim construída, devido ao receio que ela tivesse "relações com homem", nas palavras do general, e que fosse influenciada pelo cristianismo. O que veio a ocorrer após várias peripécias, narradas em detalhes pelo general. A jovem morreu torturada em defesa da religião cristã, pela mão do pai/rei, pagão. $\mathrm{Na}$ narrativa do General, esse pai, na sequência, teve punição divina e morreu atingido por um raio. Bárbara passou a ser considerada deusa dos raios e das tormentas e, na sequência, segundo o general, padroeira da artilharia, devido aos sons estrondosos produzido na batalha por essa arma, após a utilização da pólvora. Assim como as demais heroínas descritas por Micaldas Correia, Bárbara, bela, jovem e virgem, protegeu a própria castidade se recusando a casar com pretendentes pagãos e morreu em defesa da fé cristã.

$\mathrm{O}$ segundo texto de referência direta às mulheres na $A D N$ foi publicada em abril de 1944, e se refere a confecção e entrega do pavilhão nacional: "As bandeiras das damas paulistas" (FIGUEIREDO, 1944, p. 9), a pelotões da FEB, durante desfile anterior ao embarque a guerra na Europa. O texto, assinado pelo Ten-Cel Lima Figueiredo, diretor da revista, foi publicado após o editorial, o qual de antemão exaltava o desfile e a tradição militar decorrente do bandeirantismo paulista: “as tradições militares do Estado de S. Paulo são das mais brilhantes e significativas no quadro das tradições militares nacionais”, exaltando o militarismo:

[...] vocação guerreira dos paulistas [...] seus chefes eram verdadeiros capitães - fortes, destemidos, audaciosos, combativos, disciplinadores - a gente que as compunha eram lutadores da melhor têmpera, como exigiam aquelas arrojadas penetrações pela terra virgem. [...] Em todos os lances da historia militar brasileira, S. Paulo esteve presente com a contribuição de sangue, da inteligência e do patriotismo de seus filhos (EDITORIAL..., n. 359,1944 , p. 2) 
Após o estabelecimento da relação militar/bandeirante, legitimada pelo passado glorioso, o editorial cronologicamente apresenta a história de São Paulo, pautada pelo pioneirismo, expansão e desbravamento das "indústrias vanguardeiras”, para em seu ponto máximo exaltar as mulheres paulistas:

Mas não é só isso. [...] Essa vibração sabe mostrar-se plena e empolgante em oportunidades, como a que viveu o povo paulista há poucos dias, quando em cerimonia realizada no Vale do Anhangabaú, foram entregues solenemente aos soldados paulistas, que integrarão as Forças Expedicionárias do Brasil, dois pavilhões nacionais feitos pelas mãos das mulheres de S. Paulo. [...] Foi um espetáculo de uma grande e pura beleza, que espalhou reflexos em todos os recantos da alma brasileira (EDITORIAL..., n. 359, 1944, p. 3).

Ao que parece ter sido o ponto alto do desfile, a entrega de duas bandeiras aos soldados em despedida, o editorial termina com a transcrição de parte do discurso do Ministro da Guerra General Eurico Gaspar Dutra. Na sequência, o texto do Ten-Cel. Lima Figueiredo, em meio a rememoração de heroínas do passado, “[...] personagens destacadas dos grandes dramas da vida nacional", todas anteriormente apresentadas no texto de 1942, do Cap. Micaldas Correia, enaltece:

O Brasil é pequeno para o coração da mulher patrícia, quando uma idéia mirífica lhe povoa o pensamento. [...] quase todos os nossos grandiosos feitos é obra direta ou individual da mulher. [...] E quantos, sonhando com a mulher que amam, imaginando a tristeza de um lar que deixaram longe, não revigoram ao sentido perto a bandeira, para as lutas mais titânicas, esquecendo dores e desditas e conquistando glórias. [...] $\mathrm{Na}$ bandeira que as damas paulistas teceram para duas unidades da Força Expedicionária Brasileira, terão os nossos soldados, nela, representados dois elementos de encorajamento: a lembrança da pátria distante e mais particularmente, a saudade da mãe, da esposa, da filha, da noiva e da irmã que por êles oram, porque não lhes falte coragem em nenhum transe da luta (FIGUEIREDO, 1944, p. 9).

Assim como a melancólica canção germânica, a Bandeira significa levar para si um pouco da casa, da família, do afeto, das mulheres ao front. Com a função de confortar o combatente e propiciar a rememoração cotidiana sobre o porquê 
de lutar, impulsionando sua coragem e disposição à luta, frente à ameaça a um mítico mundo que deixaram e que estaria ameaçado. Além disso, desonrar a Bandeira é também desonrar as mulheres. Ten-Cel Lima Figueiredo relata a bravura de pelotões que ficaram desonrados "[...] ao sentir que seus pavilhões de suas unidades haviam caído nas mãos dos inimigos e tudo fizeram para reavê-los." (FIGUEIREDO, 1944, p. 10). A necessidade moral da presença do Pavilhão Nacional entre os combatentes explica a importância do gesto das damas paulistas e do cerimonial descrito por Lima Figueiredo:

[...] não retardaram em ofertar-lhes as bandeiras feitas por suas mãos, ponto por ponto como se esses bordados executados formassem contas de rosários, nos quais a pátria resaria [sic] preces ao nosso Deus, afim de que poupasse lágrimas à família brasileira, protegendo os bravos que se vão bater por uma melhor compreensão humano no mundo que vai raiar após a aleluia da vitória. [...] Uma grande legião foi formada - legião que tem por armas a bondade, o sacrifício e a humanidade. As combatentes dessa cruzada do bem sentiram a necessidade de ofertar uma bandeira aos jovens que em breve irão partir. (FIGUEIREDO, 1944, p. 10)

As mulheres, também combatentes na cruzada do bem, forte discurso frente a opinião pública em relação a entrada do Brasil na $2^{a}$ Guerra, usam as armas da bondade e do sacrifício. O bordado da Bandeira, como um rosário, une a guerra dos homens e a oração das mulheres. Além disso, outra bandeira, bordada a ouro, entregue aos homens em partida, nas palavras do tenente coronel, aproximava todas as mulheres, sem distinção de classe:

[...] e na execução desse propósito a faina começou. O trabalho de todas as brasileiras era aceito, fosse qual fosse sua origem étnica e social. [...] patrícias que vinham dar ao menos um ponto. [...] do pano pareceu-me emergirem arcanjos e serafins rindo de alegria, e entoando hosanas em louvor aquelas que souberam alçar tão alto, com um gesto simples, o patriotismo da mulher brasileira (FIGUEIREDO, 1944, p. 11).

Assim como as filhas de Benjamin Constant, imortalizadas no quadro "A Pátria” (1909), todas as brasileiras enlaçam, nos pontos do bordado, a Pátria, a religião, o significado da própria guerra e o futuro da nação. 
O último texto referente a mulheres na $A D N$ foi publicado em outubro de 1944 (A LEGIÃO..., 1944, p. 98) e trata de visibilizar ações da “A Legião Brasileira de Assistência da Bahia” (título da notícia). O texto, sem assinatura, em duas páginas e contendo duas fotografias, noticia o envio de comunicados das ações de mulheres da LBA, seção da Bahia, à $1^{\text {a }}$ dama Darcy Vargas. A primeira parte do texto enfatiza: “[...] foi evidenciada a presteza da mulher baiana, convocada para as fileiras do exercito da retaguarda, inscrevendo-se nos diversos setores da eficiente organização social de assistência [...]” (LEGIÃO..., 1944, p. 98).

Os elogios iniciais estão seguidos pela fotografia de um pequeno grupo de homens e mulheres em atividade de treinamento de socorro em batalha. A foto, seguida da legenda “As 'samaritanas socorristas' da LBA realizam exercícios de serviço de campanha, auxiliadas por soldados do Exército” (A LEGIÃO..., 1944, p. 98), nos mostra, em primeiro plano, a simulação de socorro de combatente ferido, em uma padiola carregada por soldados, seguindo em direção a uma ambulância, ladeada por duas enfermeiras uniformizadas. Assistindo a cena, em segundo plano, estão cerca de dez sorridentes mulheres. Após esse enfoque, o texto narra um rol de seções e ações da LBA - Bahia, expondo vários dados estatísticos sobre os/as beneficiários, sem, contudo deixar de assinalar que essas seções tinham sua "[...] autonomia, embora subordinados à Presidência.” (A LEGIÃO..., 1944, p. 98) O esforço de guerra da LBA, apresentado no texto, vai em direção a uma guerra interna relativa à pobreza através da assistência benemerente, para além do auxílio exclusivo aos soldados e suas famílias. Nesse sentido, o texto aponta os projetos:

[...] Merenda Escolar, na capital e nos subúrbios, o que tem contribuído para a sensível melhoria das condições físicas dos meninos pobres das escolas, cuja saúde é, assim, cuidada e defendida contra enfermidades resultantes da sub-nutrição. Tão perigosa em época de desenvolvimento físico e intelectual. (A LEGIÃO..., 1944, p. 99).

O olhar sobre a saúde da população brasileira, frente a exigências da guerra, percebia uma carência de vigor físico e intelectual. A militarização das sociedades, desde fins do XIX, segundo Georges Vigarello (2008), colocara a necessidade do corpo forte e saudável, inclusive para as mulheres, no centro dos debates. A percepção médica, política, militar sobre a saúde dos/as brasileiros/ as, em meio a guerra, era desoladora e exigia a tomada de ações também por 
parte do assistencialismo benemerente da LBA.

Em meio ao balanço das obras meritórias da LBA - Bahia, o texto traz uma foto sobre o Projeto "A cantina do combatente" (Figura 2). Ladeados por sorridentes damas da LBA, inclusive sua maior representante estadual: à mesa, jovens homens constritos se alimentam como se estivessem a sós, não fosse pelo olhar, solene, de um deles à objetiva. Além do gênero, as indumentárias e as posições de homens e mulheres na foto, nos apontam o contraste de lugar social. Gênero e classe demarcam o espaço de um feminino que cuida, alimentando os soldados, como mães de toda uma nação.

Figura 1 - Na "cantina do combatente", a presidente da L.B.A, na Bahia leva aos soldados e marinheiros, pessoalmente, o conforto de palavras animadoras.

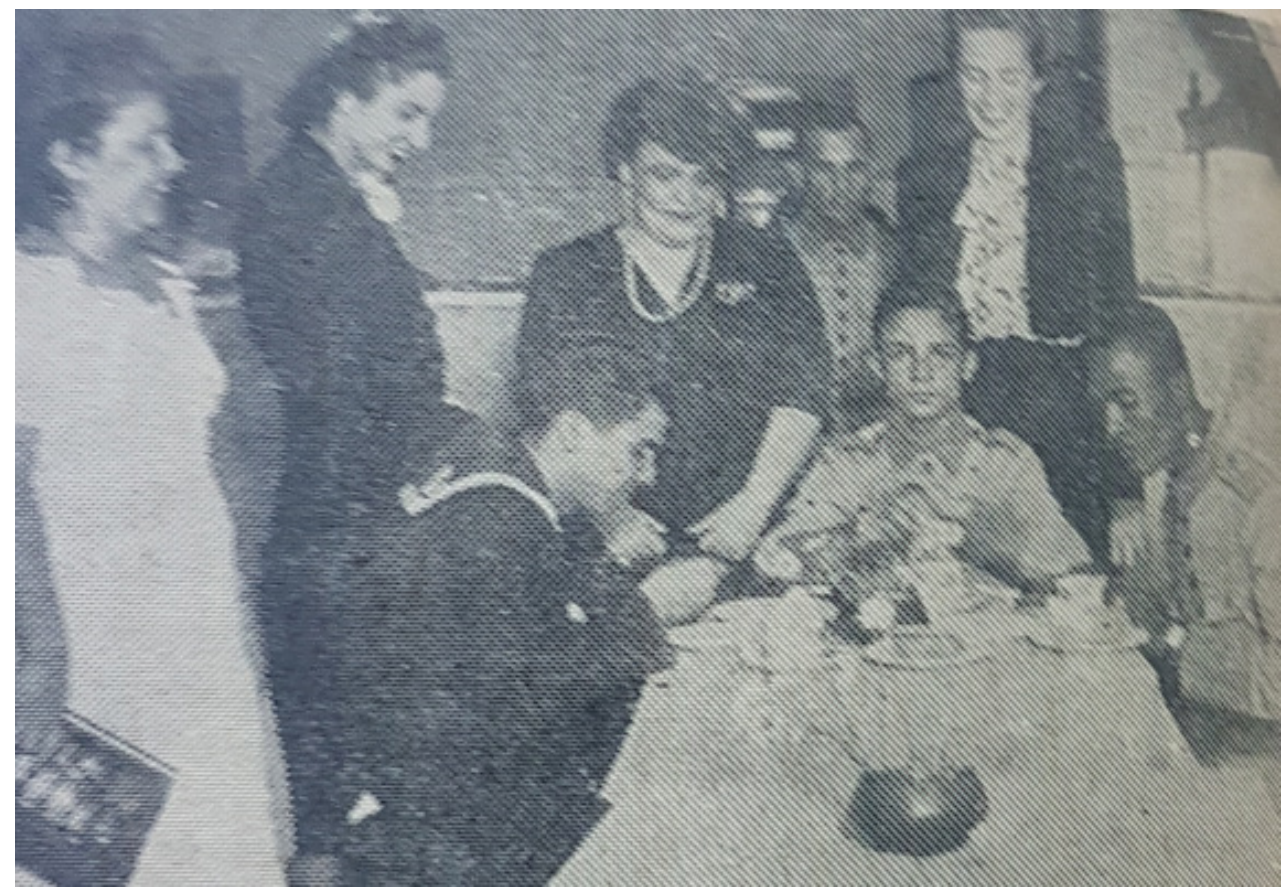

Fonte: (A LEGIÃO..., 1944, p. 66). Acervo: Biblioteca do Exército - BILIEx.

Tal como Rosa da Fonseca, Darcy Vargas e outras tantas, o feminino possível nas narrativas dessa imprensa militar em guerra, é a da mãe dos brasileiros e/ ou filhas de Benjamin Constant: cuidar fisicamente e encorajar moralmente os homens. Seja pelo exemplo de heroínas militarizadas do passado; seja pelo exemplo maternal da $1^{a}$ dama, das samaritanas, das legionárias. Cabendo a todas as brasileiras o tecer, o enlaçar a nação, armada. 


\section{Referências}

A LEGIÃO Brasileira de Assistência da Bahia. A Defesa Nacional, Rio de Janeiro, n. 365, p. 64-99, out. 1944.

A SRA. Darcy Vargas recebe a “Medalha de Guerra”. Nação Armada, Rio de Janeiro, n. 71, p. 119-135, out. 1945.

ALMANAQUE do Ministério da Guerra para o ano de 1931. Rio de Janeiro: [Imprensa Militar, 1931]. BIBLIEx.

ANDOIN-ROUZEAU, Stéphane. Exércitos e guerras: uma brecha no coração do modelo viril? In: CORBIN, Alain; COURTINE, Jean-Jaques; VIGARELLO, Georges (org.) História da virilidade: a virilidade em crise? o século XX-XXI. Petrópolis: Vozes, 2013. v. 3, p. 239-268.

ANDRADE, Cap. Dr. Carlos Sudá. Saudação à Caxias e Ana Nery. Nação Armada, Rio de Janeiro, n. 35, p. 34, out. 1942.

ARIAS NETO, José Miguel. Imprensa militar no século XIX: um balanço preliminar. Revista Navigator, [Rio de Janeiro], v. 9, n. 18, p. 55-64, 2014.

BARBOSA, Michele Tupich. Legião brasileira de assistência (LBA): o protagonismo feminino nas políticas de assistência em tempos de guerra (1942-1946). Curitiba: [s. n.], 2017.

BARRETO, Rozendo Muniz. A mãe dos brasileiros. [S. l.: s. n., 1876]. Manuscrito. Poemeto Histórico oferecido ao Inst. Hist. e Geográfico Brasileiro em 1876.

BELL, Emma; NARAYANASWAMY, Lata. Gender and Armed Conflict Supporting Resources Collection. Brighton: Institute of Development Studies: University of Sussex, 2003. Disponível em: http://www.ids.ac.uk/bridge/. Acesso em: 10 jul. 2020.

BOURDIEU, Pierre. O poder simbólico. 6. ed. Rio de Janeiro: Bertrand Brasil, 2003

BRASIL. Câmara dos Deputados. Decreto $n^{\circ}$ 2.956, de 10 de Agosto de 1938. Institui o “Dia do Enfermeiro”. Brasília: Câmara dos Deputados, 1938. Disponível em: https://www2.camara.leg.br/legin/fed/decret/1930-1939/decreto-2956-10agosto-1938-345733-publicacaooriginal-1-pe.html. Acesso: 15 jul. 2018.

BRASIL. Decreto $n^{\circ}$ 10.358, de 31 de agosto de 1942. Declara o estado de guerra em 
todo o território nacional. Brasília: Presidência da Republica, 1942. Disponível em: http://www.planalto.gov.br/ccivil_03/decreto/1930-1949/D10358impressao. htm. Acesso: 10 jun. 2018.

BRASIL. Lei n. 12605, de 3 de abril de 2012. Determina o emprego obrigatório da flexão de gênero para nomear profissão ou grau em diplomas. Brasília: Presidência da República, 2012. Disponível em: http://www.planalto.gov.br/ ccivil_03/_ato2011-2014/2012/lei/112605.htm. Acesso em: jun. 2018.

BRASIL. Ministério da Defesa.Exército Brasileiro.Maria Quitéria.Brasília:EB,2017. Disponível em: http://www.eb.mil.br/maria-quiteria-quadro-complementar-deoficiais?inheritRedirect=true. Acesso em: 23 Fev. 2017.

BRASIL. Ministério da Defesa. Exército Brasileiro. Portaria $n^{\circ}$ 650, de 10 de Junho de 2016. Aprova a Diretriz para a entronização de D. Rosa da Fonseca como Patrona da Família Militar e implantação do Dia da Família Militar (EB10-D-05.001) e dá outras providências. Boletim do Exército, [Brasília], n. 24, p. 11, jun. 2016.

BUTLER, Judith. Fundamentos contingentes: o feminismo e a questão do "pósmodernismo". Cadernos Pagu, Campinas, n. 11, p. 11-42, 2013. Disponivel em: https://periodicos.sbu.unicamp.br/ojs/index.php/cadpagu/article/view/8634457 . Acesso em: 9 jul. 2019.

CAIRE, Raymond. A mulher militar: das origens aos nossos dias. Rio de Janeiro: BIBLIEx, 2002.

CALADO, Manuel. O Valeroso Lucideno. Belo Horizonte: Itatiaia 1987. 2 v.

CAPELLA, Leila. As malhas de aço no tecido nacional: a revista A Defesa Nacional e o serviço militar obrigatório. 200 f. 1985. Dissertação (Mestrado) - Universidade Federal Fluminense, Niterói, 1985.

CARREIRAS, Helena. Oolhar dos homens: resistência e cumplicidadenas respostas masculinas à integração de mulheres nas Forças Armadas. In: MATHIAS, Suzeley Kalil (org.) Sob o signo de Atena: gênero na diplomacia e nas Forças Armadas. São Paulo: UNESP, 2009. p. p. 169-190.

CARVALHO Afonso de. In: BELOCH, Israel; ABREU, Alzira A. (org.). Dicionário Histórico-Biográfico Brasileiro (1930-1983). Rio de Janeiro: Editora Forense Universitária: FGV- CPDOC: Finep, 1984.

CARVALHO, Affonso. $1^{a}$ Bateria, fogo!. Rio de Janeiro: Civilização Brasileira, 1931. 
CARVALHO, José Murilo. Forças Armadas e Política, 1930-1945. In: CARVALHO, José Murilo. Forças Armadas e política no Brasil. Rio de Janeiro: Jorge Zahar Ed., 2005. p. 62-101.

CASTRO, Celso (org.). A família militar no Brasil: transformações e permanências. Rio de Janeiro: FGV Editora, 2018.

CIDADE, Francisco de Paula. Lily Marleen. Nação Armada, Rio de Janeiro, n. 61, p. 5-11, dez. 1944.

CORREIA, Micaldas. O heroísmo feminino: homenagem a Legião Brasileira de Assistência. Nação Armada, Rio de Janeiro, n. 36, p. 33-39, nov. 1942.

COURTINE, Jean-Jacques Introdução. Impossível virilidade. In: CORBIN, Alain; COURTINE, Jean-Jaques; VIGARELLO, Georges (org.) História da virilidade: a virilidade em crise? o século XX-XXI. Petrópolis: Vozes, 2013. v. 3, p. 7-12.

DEMOCRATAS. Partido político. Mulher, gênero \& igualdade: a conquista dos direitos. Brasília: Partido Democratas, 2019. Disponível em: http://www. mulherdemocrata.org.br/download/cartilha_maio.pdf. Acesso: 20 nov. 2019.

EDITORIAL. A Defesa Nacional, Rio de Janeiro, n. 359, 1944, p. 2.

FIGUEIREDO, Lima. As bandeiras das damas paulistas. A Defesa Nacional, Rio de Janeiro, n. 359, abr. 1944. p. 9-11.

HANHER, June E. Emancipação do sexo feminino: a luta pelos direitos da mulher no Brasil, 1850-1940. Florianópolis: Editora Mulheres, 2003.

HAYES, Robert. Nação Armada: a mística militar brasileira. Rio de Janeiro: BIBLIEX, 1991.

HOBSBAWN, Eric. Era dos extremos: o breve século XX: 1914-1991. São Paulo: Cia das Letras, 1994.

LAQUEUR, Thomas. Inventando o sexo: corpo e gênero dos gregos a Freud. Rio de Janeiro: Delume Dumará, 2001.

MARTINS, Ana Paula Vosne. Gênero e assistência: considerações históricoconceituais sobre práticas e políticas assistenciais. História, Ciências, SaúdeManguinhos (Impresso), v. 18, p. 15-34, 2011.

McCANN, Frank. Soldados da Pátria. História do Exército Brasileiro 1889-1937. 
São Paulo: Cia das Letras, 2007.

McNAMARA, Edith. As mulheres na guerra. Nação Armada, Rio de Janeiro, n. 48, p. 74-77, nov. 1943.

MELO, Silveira de. "Santa Bárbara: padroeira da artilharia”. A Defesa Nacional, Rio de Janeiro, n. 360, p. 81, maio 1944a.

MELO, Silveira de. Arcanjo São Gabriel. A Defesa Nacional, Rio de Janeiro, n. 360, p. $817,1944 b$.

MELO, Silveira de. Cronologia dos santos militares. A Defesa Nacional, Rio de Janeiro, n. 362, p. 45, 1944c.

MELO, Silveira de. O Centuriao de cafarnaún. A Defesa Nacional, Rio de Janeiro, n. 345, p. 27-30, 1943.

MONTEIRO, Vitor José da Rocha. Do "exército de sombras" ao "soldado-cidadão": saúde, recrutamento militar e identidade nacional na revista Nação Armada (1939-1947). 2010. Dissertação (Mestrado em História das Ciências e da Saúde) Fundação Oswaldo Cruz, Casa de Oswaldo Cruz, Rio de Janeiro, 2010.

MOREIRA, Rosemeri. Entre o mito e a modernidade: a entrada de mulheres na Polícia Militar do Paraná. Guarapuava: Edunicentro, 2016.

MOREIRA, Regina da Luz. Fatos \& imagens 1944: o Brasil vai à guerra com a FEB. São Paulo: FGV-CPDOC, 2018. Disponível em: https:/cpdoc.fgv.br/producao/ dossies/FatosImagens/FEB. Acesso: maio 2018.

MOREIRA, Rosemeri. Virilidade e o corpo militar. História: Debates e Tendências, Passo Fundo, v. 10, n. 2, p. 321-335, jul./dez. 2010.

MOSSE, George L. La imagen del hombre: la creacíon de la moderna masculinidad. Madrid: Talasa, 2000.

NASCIMENTO, Fernanda de Santos. A revista A Defesa Nacional e o projeto de modernização do Exército brasileiro (1931-1937). 2010. Dissertação (Mestrado) PUC, Porto Alegre, 2010.

NASCIMENTO, Fernanda Santos. A imprensa militar no século XIX: o periódico o “Militar Brioso”, Revista Navigator, [Rio de Janeiro], v. 9, n. 18, p. 27-34, 2014.

NASCIMENTO, Fernanda Santos; ELIBO JUNIOR, Antonio Manoel. A revista 
A Defesa Nacional: o autoritarismo, os intelectuais e os militares no governo Vargas (1930-1937). Temporalidades, Belo Horizonte, v. 7, n. 1, p. 63-78, jan./abr. 2015.

O HEROÍSMO das legionárias de Anna Nery!. Nação Armada, Rio de Janeiro, n. 66, p. 135, maio 1945.

OLIVAR, José Miguel Nieto. A angústia dos corpos indóceis: prostituição e conflito armado na Colômbia contemporânea. Pagu [online], São Paulo, n. 31. p. 365-397, 2008. Disponível em: http://www.scielo.br/scielo.php?script=sci arttext\&pid=S0104-3332008000200016\&lng=en\&nrm=iso. Acesso em: 2 abr. 2020.

OLIVEIRA, Susane Rodrigues. As mulheres indígenas nas lutas contra a opressão e dominação colonial no Peru (séculos XVI-XIX). 147f. 2006. Tese (Doutorado em História) - UnB, Brasília, 2006.

PERROT, Michele. Mulheres públicas. São Paulo: Fundação Editora da Unesp, 1998.

PRADO, Maria Ligia. América latina no século XIX: tramas, telas e textos. São Paulo: Edusp, 1999.

QUETÉL, Claude. Mulheres na guerra: 1939- 1945. São Paulo: Larousse do Brasil, 2009.

RUI, José Carlos. As mulheres de Tejucupapo - a defesa armada dos direitos do povo. Vermelho, São Paulo, 16 abr. 2016. Cultura Nacional. Disponível em: http:// www.vermelho.org.br/noticia/279398-1. Acesso em: 20 nov. 2019.

SALAS, Elizabeth. Soldaderas in the mexican military: mith and history. Austin: University of Texas Press, 1990.

SANTOS, Francisco Ruas. Coleção bibliográfica militar. Rio de Janeiro: BibliEx. 1960.

SCOTT, Joan. Gênero: uma categoria útil de análise histórica. Educação e Realidade, Porto Alegre, v. 16, n. 2, p. 5-22, jul./dez. 1990.

SIMILI, Ivana Guilherme. Mulher e política: a trajetória da primeira dama Darcy Vargas (1930-1945). São Paulo: Editora UNESP, 2008.

Visita o Ministério da Guerra. Nota. Diário de Notícias, Rio de Janeiro, 22 fev. 
1942, p. 8.

SOIHET, Rachel. O feminismo tático de Bertha Lutz. Florianópolis: Ed. Mulheres; Santa Cruz do Sul: EDUNISC, 2006.

TREVISAN, Leonardo. As obsessões patrióticas: origens e projetos de duas escolas de pensamento político do Exército Brasileiro. 1993. Tese (Doutorado) - USP, São Paulo,1993.

VIGARELLO, Georges. Treinar. In: CORBIN, Alain; COURTINE, Jean-Jaques; VIGARELLO, Georges (org.) História do corpo: as mutações do olhar: o século XX. 2. ed. Petrópolis: Vozes, 2008. v. 3, p. 197-250.

\section{Notas}

${ }^{1}$ Doutora em História. Professora do curso de graduação em História e do PPGH Universidade Estadual do Centro-Oeste-PR. rosemeri1moreira@gmail.com. Este texto é parte de uma pesquisa realizada durante estágio pós-doutoral, em 2018, na Fundação Getúlio Vargas - Rio de Janeiro, sob tutoria do Dr. Celso Castro.

${ }^{2}$ Percebido, no mais das vezes, de forma a-histórica e naturalizada, ao longo do século XIX que os termos masculinidade e virilidade foram considerados como imbricados, quase sinônimos (COURTINE, 2013; ANDOIN-ROUZEAU, 2013). Stéphane AndoinRouzeau (2013, p. 239), assinala que a "cultura ocidental havia relacionado o mito viril estritamente ao fato militar e a atividade guerreira, a ponto de fazer da preparação ao combate, e do próprio combate, o critério, senão único, ao menos decisivo, da virilidade". Também para George Mosse (2000), em texto clássico ("La imagen del hombre"), foi no século XIX que a virilidade foi militarizada, o que ele chama de invenção da virilidade moderna.

${ }^{3}$ Esse debate se impôs a partir de pesquisa referente a criação das chamadas "Organização Feminina Auxiliar de Guerra” (OFAGs), que existiram entre 1942-1945, nas cidades de São Paulo, Rio de Janeiro e Santos. Inexistentes na historiografia sobre o período, esses agrupamentos de mulheres foram responsáveis por diversas tarefas voltadas ao dito esforço de guerra. No processo de busca por fontes me deparei com a inexistência de documentos oficiais, relativas a eles, no Arquivo do Exercito Brasileiro (AHEX). Entretanto, encontrei diversas reportagens diretas e indiretas sobre mulheres, em importantes periódicos militares, aqui analisados.

${ }^{4}$ A despeito da ausência de um debate que historicize as significações sobre "Militarismo", de forma provisória, considero que a "concepção de militar - militarismo e militarização - pressupõe dois enfoques que se entrelaçam. Primeiro, externamente: como a função/ organização e capacidade para a guerra, a arte de sobrepor-se com a utilização da força, a capacidade para a ação. Em segundo, pensado internamente e a partir de dois fundamentos relacionais: a autoridade baseada na "situação de guerra" contra um inimigo (estrangeiro, subversivo, delinquente, etc.) que precisa ser neutralizado, e o "medo de ser contra" (BOUDIEU, 2003, p. 202) - ser o inimigo - e deixar de fazer parte do grupo" (MOREIRA, 2016, p. 160). Em relação a última premissa - o espírito de corpo - segundo Bourdieu (2003, p. 202), é o fundamento último da militarização. O autor 
refere-se ao processo de militarização dos partidos políticos, mas que também descreve todo processo que busca construir unicidade, homogeneidade de qualquer instituição, como é o caso das Forças Armadas e também das Polícias Militares. Além disso, a ideia de militarismo abrange uma série de gestuais, posturas corporais e frases padronizadas, que exacerbam a relação entre seus integrantes. Relação pautada, primordialmente, pela disciplina e hierarquia.

${ }^{5}$ A invasão da Polônia pela Alemanha nazista, em $1^{\text {a }}$ de setembro de 1939 , é considerado o marco inicial da $2^{\text {a }}$ Guerra Mundial (HOBSBAWN, 1994).

${ }^{6}$ Pedro Calmon, Gustavo Barroso, Menotti del Picchia, Azevedo Amaral, dentre outros (MONTEIRO, 2010, p. 43).

${ }^{7}$ Dutra atingiu o generalato em 1932. Comandava a $1^{\text {a }}$ Brigada de Infantaria, quando dos levantes de 1935. Foi Ministro da Guerra de 1936 a 1945. Ocupou a Presidência entre 1946 e 1950 (CARVALHO..., 1984, p. 1126-1154). General Pedro Aurélio de Góes, o Chefe do Estado-Maior do Exército no Estado Novo, foi Ministro da Guerra de 1934 e 1935.

${ }^{8}$ Um dos chamados jovens turcos. No retorno da Prússia ao Brasil, participou da fundação da revista "A Defesa Nacional". É também um dos fundadores da Biblioteca do Exército.

'Segundo Leila Capella, a intenção dos jovens turcos era o afastamento da uma política considerada mesquinha e partidária, uma vez que isso poderia levar à quebra de hierarquia e disciplina da corporação. A preocupação desses oficiais era direcionar o Exército, para a o que consideravam a grande política, o desenvolvimento nacional (CAPELLA, 1985, p. 84). Esses jovens oficiais tiveram formação germanófila na gestão de Hermes da Fonseca (titular da pasta da Guerra no governo de Afonso Penna -1906/1909).

${ }^{10}$ Conforme Nascimento (2015) no editorial de Outubro de 1913 consta que foram foram fundadores da revista: Estevão Leitão de Carvalho, Mario Clementino de Carvalho, Joaquim de Souza Reis, Bertoldo Klinger, Francisco de Paula Cidade, Brasilio Taborda, Epaminondas de Lima e Silva, Cesar Augusto Parga Rodrigues, Euclides Figueiredo, José Pompeo Cavalcânti de Albuquerque, Jorge Pinheiro, Amaro de Azambuja Villa Nova.

${ }^{1}$ Entre 1882 (ano de sua fundação) e 1889, foi denominada Revista do Exército Brasileiro; no período de 1899 a 1908, teve o nome de Revista Militar; entre 1911 e 1923, foi chamada de Boletim Mensal do Estado-Maior do Exército; de 1924-1981, seu nome foi Revista Militar Brasileira; e, de 1982 aos dias atuais, retomou seu nome original, Revista do Exército Brasileiro (MONTEIRO, 2010, p. 71).

${ }^{12} \mathrm{~A}$ comissão de redação estava a cargo da $5^{\mathrm{a}}$ seção do E.M. que tinha o Cel. José de Castello Branco, o Ten-Cel Lucio Corrêa e Castro, o Maj. José Silvestre de Mello e o Cap. Francisco de Paula Cidade, como redatores principais (ALMANAQUE..., 1931, p. 678).

${ }^{3}$ Contabilizadas por Monteiro, de novembro de 1939 a março de 1947, seu período de veiculação, a revista teve 2.488 páginas com propagandas, com uma média aproximada de trinta páginas de propagandas por exemplar (MONTEIRO, 2010, p. 43).

${ }^{14} \mathrm{~A}$ compreensão de que masculinidade(s) e feminilidade(s) são construções históricas está ancorada na categoria de análise Gênero, a qual, problematiza a construção dos corpos e do dimorfismo sexual, levando em consideração a formação, a crença, as (re)significações da dicotomia, e suas reverberações no plano econômico, político e cultural. A crença estruturante na invenção de dois corpos, dois sexos, dois desejos, que 
correspondem a qualificações e atribuições sociais - generificadas - entre as pessoas (ver: BUTLER, 2013; LAQUEUR, 2001; SCOTT, 1990).

${ }^{15} \mathrm{~A}$ partir da década de 1990, principalmente influenciada pelos debates pósestruturalistas, a problematização referente a História do Corpo, assinala a construção de discursos relativos a invenção do sexo dual: duas genitálias naturalmente/ cientificamente excludentes e diferentes em termos físicos, morais e intelectuais (LAQUEUR, 2001), perpetrada nos saberes da Biologia a da Medicina, e que hierarquizou os corpos, a partir das leituras dicotomizadoras, entre força e fraqueza; ação e submissão; razão e sensibilidade, etc..

BRASIL (1942).

${ }^{17}$ No Rio de Janeiro, em 31 de março de 1926, pelo Decreto-Lei n. 17.268, foi dada a denominação de Ana Néri à Escola de Enfermeiras do Departamento Nacional de Saúde Publica.

${ }^{18}$ A ideia de criação de uma força militar para participar do conflito surgiu em fevereiro de 1943, durante o encontro do presidente dos EUA Franklin Roosevelt e Getúlio Vargas, em Natal, Rio Grande do Norte. (MOREIRA, 2018)

${ }^{19}$ Para além da maternidade empírica, a qual também se encontra mergulhada na historicidade, enquanto discurso político, a maternagem é a consideração da capacidade intrínseca e definidora das mulheres no cuidado com o outro, no âmbito privado (filhos, maridos, pais, idosos, doentes, etc.) e que foi expandida para a esfera pública, ampliando as demarcações da construção anterior. Pelo menos desde fins do século XIX, e presente, principalmente, em enunciados de movimentos sufragistas a expansão da maternidade foi transformada em prática política e expandida para toda a sociedade (Ver: HANHER, 2003; SOIHET, 2006).

${ }^{20}$ Relatos sobre essas valentes mulheres se encontra na obra "Valeroso Lucideno", de 1648, escrita pelo frei português Manoel Calado (1987).

${ }^{21}$ Celebradas por grupos de partidos de diferentes matizes políticas tais como o Portal Vermelho (RUI, 2016) e cartilha do Partido Democratas (DEMOCRATAS, 2019)

${ }^{22}$ Maria Quitéria é considerada "patrono" do quadro complementar de oficiais do Exército Brasileiro, desde 1996.

${ }^{23}$ Disponível em: BRASIL (2017)

${ }^{24}$ BRASIL. Ministério da Defesa. Exército Brasileiro. Portaria no 650, de 10 de Junho de 2016.

${ }^{25}$ BRASIL (2012).

${ }^{26}$ A música é originária de um poema escrito, em 1915, por Hans Leip, soldado alemão da $1^{\text {a }}$ Primeira Guerra Mundial. Foi musicada pelo compositor Norbert Shultze, em 1938. Lily Marleen tornou-se a principal canção da $2^{\mathrm{a}}$ Guerra, após transmissão diária pelas rádios alemãs. Uma das versões mais famosas é a cantada por Marlene Dietrich (19011992), cantora e atriz alemã, naturalizada estadunidense em 1939.

${ }^{27}$ Sobre Guerras, conflitos e prostituição Ver: Olivar (2008); Quetél (2009); Bell e Narayanaswamy (2003). 
${ }^{28}$ Além desse texto, em outras edições o mesmo general escreveu sobre a história da Igreja Católica e de seus santos: sobre "O Centuriao de cafarnaún” (MELO, 1943, p. 2730); Sobre o “Arcanjo São Gabriel”, patrono dos altos comandos e Estado Maior, o então Cel. Silveira de Melo, aponta as hierarquias dos anjos, e estabelece uma franca relação entre catolicismo e militarismo. Em meio aos santos, prevalece a história do Império Romano, dos reis de Israel, e trajetórias (MELO, 1944b, p. 817). Na edição de janeiro de 1944 publicou a "Cronologia dos santos militares", em que defende que "Mais do que homens de farda, os militares devem compenetrar-se do serviço das armas como desempenho de um apostolado" (MELO, 1944c, p. 45). 